\title{
Victimization of Facebook Users: An Empirical Study among Female Students in Tangail
}

ISSN: 2311-8636 (Print)

ISSN: 2312-2021 (Online)

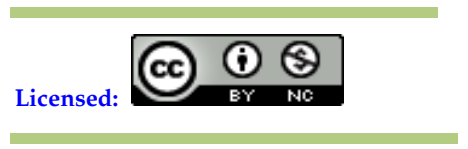

Source of Support: Nil

No Conflict of Interest: Declared

*Email for correspondence:

mahmudaakterhappy72@gmail.com

\section{Mohammad Ashraful Alam ${ }^{1}$, Mahmuda Akter ${ }^{2 *}$ Saikat Alam Santona ${ }^{3}$}

\footnotetext{
${ }^{1}$ Associate Professor, Department of Criminology and Police Science, Mawlana Bhashani Science and Technology University, Tangail, BANGLADESH

${ }^{2}$ Lecturer, Department of Criminology and Police Science, Mawlana Bhashani Science and Technology University, Tangail, BANGLADESH

${ }^{3}$ MS Students, Department of Criminology and Police Science, Mawlana Bhashani Science and Technology University, Tangail, BANGLADESH
}

\begin{abstract}
Social networking site is an important area of research. It is a known fact that young adults and teenagers, especially students are the most avid users of online Social networking sites which have a great impact on their lives. Yet, little is known about the sardonic experiences of students in social networking sites. With approximate 22.880 million users Facebook holds its number one popularity rank. Therefore, this paper takes Facebook as commissar of these Social Networking sites and focuses to provide an insight on the victimization of Female student and tends to explore the current nature and causes of female Facebook victimization. Female students are opted because they are more vulnerable in these sites than male. This paper reports the findings of a research work that was carried out in the higher secondary educational institutions in Tangail by using a nonprobability purposive sample of 15 to 26 years aged female students. 70 samples were collected through a structured questionnaire and the gleaned data was analyzed by using SPSS. This study demonstrates, although social networking site have opened up a new way of socialization, respondents had experienced several types of cyber crime in Facebok. Such experiences create a state of insecurity, depression, fear, isolation and to a very large extent suicide. It is relatively a new phenomenon and hopefully both the effective technical strategy along with public consciousness used as a useful tool to reduce female vulnerability in Facebook from individual to national level in Babgladesh.
\end{abstract}

Keywords: Facebook, Female Students, Victimization, Insecurity, Depression

\section{INTRODUCTION}

Technological advancement and social networking sites along with the creation of smart digital devices and their applications allow people to access social media anywhere. Social networking increases our ability to communicate with large number of people at any time of 
the day and night. It transformed everything from private to public, from local to global, from fleeting to permanent and from trustworthy to unreliable. It also allows our instant access to a plethora of information which can greatly benefit our lives but can simultaneously become a gateway to online victimization. By giving up privacy for the online world of instant gratification, women are unknowingly helping create an online culture that breeds victimization and serves to ignite assaults that were traditionally found off-line. Cyber harassment via e-mails, cyber stalking, cyber pornography, defamation, morphing, e-mail spoofing are the most common forms of cybercrime done against women (United Nations Broadband Commission for Digital Development, 2010). In Bangladesh, Nowadays, among the popular social networking sites of the world like- Facebook, youtube, Whatsapp, Wechat, tumblr, Viber, Instragram, twitter, google+; Facebook is mostly used by the people which has an adverse affect on users and its effect on women is more concerning.

Women have been deliberatively and frequently are subjected to violence in every sphere of their life. In Bangladesh, there are hardly any women or girls those who are not the victim of any violence. Outside of their house they are experiencing crime and harassment; in house domestic violence and as a user of cyber world they are not safe at all. According to Bangladesh Telecommunication Regulatory Commission (BTRC), 80 percent internet users of Bangladesh are on social networking website Facebook (Maruf, Islam \& Ahmed, 2010). In June 2016, internet users of Bangladesh were 38.9\% and Facebook users' percentage was $12.89 \%$ (The Daily Bangladesh Somoy, 2016). Socialization through social networking websites has become a favorite hobby for self-supporting, educated, independent, modern women of the 21st Century (Halder \& Jaishankar, 2013).

Social Networking sites are potential mine for criminals where available information of users is found that can be further used to any offensive purpose. Users of Facebook can post what they will have been doing at certain time hence provide the potential offender a chance to do something wrong (Dinerman, 2011). 53.66\% students were using Facebook most days and $30 \%$ stated that they didn't use privacy settings. Without privacy settings Facebook use provides opportunities to offender (Maruf, Islam \& Ahmed, 2010). Internet privacy is comparatively more complex than physical privacy hence defense is also complex. Researcher classify four causes of users privacy leaks namely users' limitation, design flaws and limitations, implicit flows of information and clash of incentives. The most probable attack on Facebook may be verbal attack, targeted friend attack, fake account and cloning attack or permanent takeover of an account (Soron \& Chowdhury, 2016).

Bangladesh can be characterized as a country of extensive Facebook users because it makes people more associative than ever before. People can make profile in a compact system, conduct some sorts of private activity and chat with any of their friend through Facebook. Women users discuss the needs, tips and even their mood swings with their virtual friends who become emotional comfort zones for them either by writing on walls of some group, community forums or on their friend's profiles and thus being potential victims for online sexual assault, stalking, identity theft, cyber gendered harassment, internet infidelity and even domestic violence by a suspicious spouse or even ex-spouse (Halder \& Jaishankar, 2013). In addition, Facebook and other social networking websites are used by criminals with a view to committing crime, distributing propaganda; unauthorized sharing that threatens intellectual property rights, hacking, phishing and texting sexual content and even instigating domestic violence (Soron \& Chowdhury, 2016). Because of overuse, disclosure of information, lower literacy to privacy policies and chatting with unknown person women sometimes encountered with many problems from simple to severe. The problems can sometimes be resulted in 
isolation, real world crime, study drop or even suicide (Lovejoy, 2009). The use of Facebook has become infectious among women in Bangladesh. To have a Facebook profile portrait a more sociable image of the individual. Although Facebook is used for academic purposes, to keep in touch with friends and to find new friends irrespective of gender; female users have a greater tendency to express their private information and daily activities through Facebook. Consequently their potential risk of victimization is greater.

To assess the contribution of individual and situational factors on cyber victimization, Ngo \& Paternoster (2011) observe cyber victimization from the lens of routine activity, lifestyle and self-control theory. Again lower self-control is related to the likelihood experiencing online harassment by stranger or non-stranger. While exploring the extent of users' disclosure of Facebook information and related privacy risks Jeet (2012) found that minimal information is required to create a Facebook account and allows other users to post notes, messages or birthday wishes and cross linked tagging .It also found that the most active users disclose the most, users know about privacy policy but don't use them. Again information such as likes, interests and pictures are available to all the Facebook friends. So, potential offenders could have a chance to communicate with the victim, to access information about the victim, to disseminate information or pictures of the victim, and to get in touch with friends of the victim. (Notar, Padgett \& Roden, 2013) In a study forty-seven percent said they restricted access to their profile because they are generally cautious and 38\% because they had heard something concerning. Facebook promotes gossiping and rumor and may cause privacy invasion. Facebook users have a limited understanding of privacy settings in social network services is partially true (Livingstone, 2008). Criminals use Facebook for various illegal activities ranging from stalking, hate speech, bullying to sexting and grooming. Many unlawful activities are revealed and sometimes incitement for real world chaos comes from Facebook (Dinerman, 2011).

There is abundance of research on Facebook usage, but in the context of Bangladesh, there is hardly any study to address women cyber victimization. This research attempts to show the current nature and causes of cyber victimization among women in Bangladesh. It will also try to explore consequences of such victimization. In this Information Communication ear, this research will found helpful for policy makers and the users of Facebook as well.

\section{OBJECTIVES}

The principle aim of this study was to explore the current posture of cyber victimization in women Facebook users in Bangladesh. To fulfill this, the additional objectives of this study was the followings-

- To find out the root causes behind such cyber victimization through the use of Facebook among women.

- To identify the consequences of the use of cyber victimization among women.

- To search for effective prevention policy to reduce the cyber victimization among women.

\section{Research Methodology}

Descriptive type research design was used to conduct this study. In Bangladesh, Facebook users are in everywhere. Tangail municipal was selected as study area because there is a lot of renowned educational institution with a huge number of students considering the feasibility of data collection time and resources. All the female students of college level were considered as 
the population of this study. By using non-probability purposive (Judgmental) sampling 70 respondents were selected. Survey method was used to collect data through structured questionnaire of both open ended and close ended questions that includes five major sectionsthe socio-demographic information of the respondents, opinion about their situation of Facebook usage, the nature and causes of victimization, consequences of victimization and opinion about some preventive measures of such victimization. After coding process, data was imputed into the format of SPSS data editor and desirable tables and analysis was made from it. This study mostly used descriptive statistics for analyzing data and to present them.

\section{FINDINGS AND ANALYSIS OF THE STUDY}

\section{Socio Demographic characteristics of respondents}

Table 1: Socio Demographic characteristics of respondents

\begin{tabular}{|c|c|c|c|}
\hline \multicolumn{2}{|c|}{ Socio Demographic characteristics } & Number & Percent (\%) \\
\hline \multirow[t]{4}{*}{ Age group } & $15-17$ & 32 & 45.7 \\
\hline & $18-20$ & 28 & 40.0 \\
\hline & $21-23$ & 7 & 10.0 \\
\hline & $24-26$ & 3 & 4.3 \\
\hline \multicolumn{2}{|r|}{ Total } & 70 & 100.0 \\
\hline \multirow[t]{2}{*}{ Marital Status } & Married & 8 & 11.4 \\
\hline & Unmarried & 62 & 88.6 \\
\hline \multicolumn{2}{|r|}{ Total } & 70 & 100.0 \\
\hline \multirow[t]{2}{*}{ Religion } & Muslim & 61 & 87.1 \\
\hline & Hindu & 9 & 12.9 \\
\hline \multicolumn{2}{|r|}{ Total } & 70 & 100.0 \\
\hline \multirow[t]{8}{*}{ Respondents Family Income (Taka) } & $6000-10000$ & 13 & 18.6 \\
\hline & $11000-15000$ & 12 & 17.1 \\
\hline & $16000-20000$ & 16 & 22.9 \\
\hline & $21000-25000$ & 8 & 11.4 \\
\hline & $26000-30000$ & 4 & 5.7 \\
\hline & $31000-35000$ & 2 & 2.9 \\
\hline & $36000-40000$ & 3 & 4.3 \\
\hline & 41000 to above & 12 & 17.1 \\
\hline \multicolumn{2}{|r|}{ Total } & 70 & 100.0 \\
\hline
\end{tabular}

According to this study, Table 1 interprets the age group of respondents. In this study, the age group of students classifies in different age group. Here, maximum $45.7 \%$ respondent belongs in 15 to 17 age group; whereas, only $4.3 \%$ respondents belongs in 24 to above age group. The highest respondent belongs to the age group of 15 to 17 or teenaged. So, teenage female students are mostly vulnerable to Facebook victimization. In addition, Table 1 also represents the marital status of respondent that among 70 respondent 88.6 percent are unmarried and only 11.4 percent are married. So, it can be said that unmarried female are more likely to be the victim. Besides, Table 1 show the religion of respondents where most of the respondents (87.1 percent) respondents are Muslim. On the other hand, the rest of $12.9 \%$ respondents are Hindu. Moreover, Table 1 also represents the monthly family income of the respondent. Here, the income is categorized into certain amount from 6000 to 41000 and above. The mean income is 25100, median is 20000 and mode is 20000. Maximum number (22.9 percent) respondent 
belongs 16000 to 20000 income group whereas 18.6 percent respondent belongs to 6000 to 10000 income groups. So, most of the respondent belongs to middle class family.

Current State of Facebook Usage

Table 2: Current State of Facebook Usage

\begin{tabular}{|c|c|c|c|}
\hline \multirow{8}{*}{ Spending Hours } & Current State of Facebook Usage & Number & Percent (\%) \\
\hline & $1 \mathrm{hr}$. & 1 & 1.4 \\
\hline & 7 hrs. & 17 & 24.3 \\
\hline & 14 hrs. & 7 & 10.0 \\
\hline & 21 hrs. & 3 & 4.3 \\
\hline & 28 hrs. & 11 & 15.7 \\
\hline & 35 hrs. & 5 & 7.1 \\
\hline & 42 hrs. & 4 & 5.7 \\
\hline \multirow{4}{*}{$\begin{array}{l}\text { Place of Facebook } \\
\text { Uses }\end{array}$} & Total & 70 & 100.0 \\
\hline & At home & 44 & 62.9 \\
\hline & At college & 9 & 12.9 \\
\hline & Constantly & 17 & 24.3 \\
\hline \multirow{4}{*}{$\begin{array}{l}\text { Purpose of Using } \\
\text { Facebook }\end{array}$} & Total & 70 & 100.0 \\
\hline & For academic purpose & 17 & 24.3 \\
\hline & To be connected with friends & 64 & 91.4 \\
\hline & To find new friends & 16 & 22.9 \\
\hline \multirow{4}{*}{$\begin{array}{l}\text { Types of Friends } \\
\text { in Facebook }\end{array}$} & $\begin{array}{r}\text { Total } \\
\end{array}$ & 70 & 100.0 \\
\hline & Only acquaintance(real friends) & 23 & 32.9 \\
\hline & Friends of friend & 36 & 51.4 \\
\hline & Everyone & 11 & 15.7 \\
\hline \multicolumn{2}{|c|}{$\begin{array}{ll} & \text { Total } \\
\end{array}$} & 70 & 100.0 \\
\hline
\end{tabular}

In this study, Table 2 shows the weekly spending hours in Facebook of the respondent. Maximum number of respondents (31.4 percent) spent 70 hours on Facebook weekly that means in an average 10 hours per daily basis whereas 24.3 percent respondent spent at least one hour in Facebook daily which means 7 hours weekly. According to use and gratification theory of media consumption, individual use media to gratify their need. The cognitive and social interactive needs of a person can be fulfilled through Facebook usage. Thus the hours of Facebook usage indicates that student use Facebook to increase their social interaction by sharing something with friends and gratify their need. In addition, Table 2 also represents the place of Facebook usage. The places are divided into three category, namely home, college or constantly connected. The table shows that 62.9 percent users are using Facebook at their home while 24.3 percent are constantly connected to Facebook irrespective of their location.

Moreover, Table 2 also focuses on the purpose of using Facebook by the respondent. Here, most of the responses $(91.4 \%)$ has found for to be connected with the friends while 24.3 percent respondents using Facebook are on academic purpose, whereas $22.9 \%$ responses for searching new friends. So, most of the female students are use social networking sites for to be connected with their friends than their academic works. Table 2 also represents on the type of friends respondent have in their friend list. Following table shows that 51.4 percent respondent used to accept friend requests of those they don't know only on the 
basis of mutual friend and 32.9 percent are connected with only their acquaintance. 15.7 percent respondent allows less known person as their Facebook friend.

\section{Nature of Crime Victimization in Facebook}

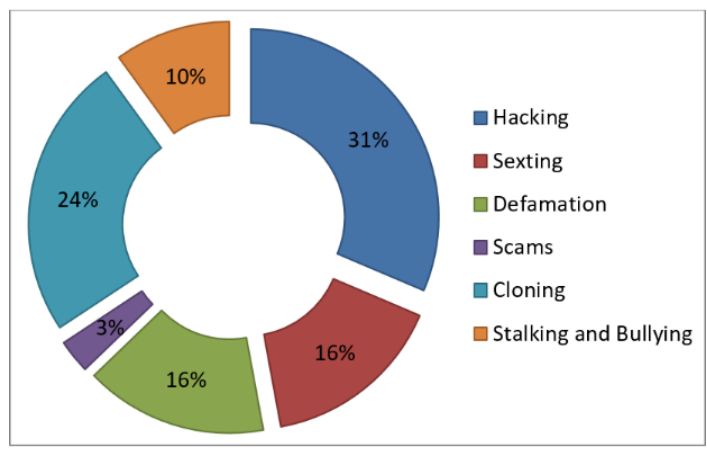

Figure 1: Nature of Crime Victimization in Facebook

In this study, Figure 1 shows the nature of Facebook enabled crimes conducted against female users. Here, the crime is categorized in six different types namely hacking with account takeover and illegal intrusion, cloning, cyber stalking, cyber bullying, defamation and scams. The figure interprets that 31.40 percent respondent has subjected to hacking, 24.30 percent respondent has subjected to cloning that means their identity was theft and reused.15.70 percent respondent has experienced either humiliation or stalking through Facebook. The scam attack in Facebook is less significant comparatively other crimes and the percentage is only 2.90.So, hacking still holds its number one position in Facebook but the amount of other crime is not negligible at all.

Table 3: Nature of Crime Victimization in Facebook

\begin{tabular}{|c|c|c|c|}
\hline \multirow{6}{*}{$\begin{array}{l}\text { Times of } \\
\text { Victimization in } \\
\text { Facebook }\end{array}$} & Nature of Victimization on Facebook & \multirow{2}{*}{$\frac{\text { Number }}{49}$} & \multirow{2}{*}{$\frac{\text { Percent (\%) }}{70.0}$} \\
\hline & Once & & \\
\hline & Twice & 7 & 10.0 \\
\hline & Trice & 3 & 4.3 \\
\hline & Four times & 3 & 4.3 \\
\hline & Five times & 8 & 11.4 \\
\hline \multicolumn{2}{|r|}{ Total } & 70 & 100.0 \\
\hline \multirow{3}{*}{$\begin{array}{l}\text { Method of } \\
\text { Victimization }\end{array}$} & Profile information & 33 & 47.1 \\
\hline & Texting & 24 & 34.0 \\
\hline & Images & 13 & 18.6 \\
\hline \multicolumn{2}{|r|}{ Total } & 70 & 100.0 \\
\hline \multirow{2}{*}{$\begin{array}{l}\text { Importation of Act in } \\
\text { Physical world }\end{array}$} & Yes & 11 & 15.7 \\
\hline & No & 59 & 84.3 \\
\hline \multicolumn{2}{|r|}{ Total } & 70 & 100.0 \\
\hline \multirow{2}{*}{$\begin{array}{l}\text { Person Responsible } \\
\text { for Victimization }\end{array}$} & Known & 25 & 35.7 \\
\hline & Unknown & 45 & 64.3 \\
\hline \multicolumn{2}{|c|}{$\begin{array}{ll} & \text { Total } \\
\end{array}$} & 70 & 100.0 \\
\hline
\end{tabular}


In this study, Table 3 reveals that 30 percent respondent has subjected to re-victimization among them 11.4 percent has experienced a single act for 5 times, 10 percent has experienced same victimization for 2 times of and 4.3 percent respondent has experienced 3 or four times of same victimization. Besides, Table 3 represents the method of victimization. About 47.1 percent respondent was victimized through profile information and 18.6 percent was victimized through images. The percentage of victimization through texting is not negligible. Moreover, Table 3 shows the frequency of real world crime According to space transaction theory the act of cyberspace could have a chance to be imported in real world. Here, in 15.7 percent cases the act was imported in real world. So, it could be said that Facebook related crime has a chance to be imported in real world. Furthermore, Table 3 also focuses on either the perpetrator of the act is known to the users or not .In most of the cases (64.3 percent) perpetrator was unknown to the victim. Only 35.7 percent perpetrator was known to the victim. So, unknown people are most probable threat to the respondent.

\section{Causes of Victimization}

Table 4: Causes of Victimization in Facebook

\begin{tabular}{|l|l|c|c|}
\hline \multirow{4}{*}{ Causes } & Causes of Victimization & Number & Percent (\%) \\
\cline { 2 - 4 } & Lack of awareness or misuse of trust & 12 & 17.1 \\
\cline { 2 - 4 } & Lack of security setting & 12 & 17.1 \\
\cline { 2 - 4 } & More expressiveness in Facebook & 23 & 32.9 \\
\cline { 2 - 4 } & Perpetrator was skilled & 15 & 21.4 \\
\cline { 2 - 4 } & Moral devaluation & 37 & 52.9 \\
\hline \multicolumn{2}{|c|}{ Total } & $\mathbf{7 0}$ & $\mathbf{1 0 0 . 0}$ \\
\hline \multirow{2}{*}{$\begin{array}{l}\text { Liability } \\
\text { for this act }\end{array}$} & Only offender & 52 & 74.3 \\
\hline \multicolumn{2}{|c}{ Total } & $\mathbf{7 0}$ & 25.7 \\
\hline
\end{tabular}

From Table 4, this study shows the causes of victimization. Among all respondents, 52.9 percent respondent blaming moral devaluation of the perpetrator as the cause of victimization and 32.9 percent said that their more expressiveness in Facebook was the cause of their victimization. So, from victim's point of view this deviancy in Facebook is the result of moral devaluation. Besides, Table 4 also presents the perceptions of victim about the liability of the act. Study shows that 74.3 percent victim inculpates the offender for this act and 25.7 percent respondent concedes their guiltiness to their victimization. So, the liability of the act mostly relies on the offender.

\section{Major Consequences of Victimization}

Table 5: Consequences of Victimization

\begin{tabular}{|c|l|c|c|}
\hline \multirow{4}{*}{ Major Consequences } & Consequences of Victimization & Number & Percent (\%) \\
\cline { 2 - 4 } & Helplessness /Insecurities & 27 & 38.6 \\
\cline { 2 - 4 } & Mental suspension & 4 & 5.7 \\
\cline { 2 - 4 } & Social and family isolation & 4 & 5.7 \\
\cline { 2 - 4 } & Anxiety \& aggression & 21 & 30.0 \\
\cline { 2 - 4 } & Fear(further victimization) & 5 & 7.1 \\
\cline { 2 - 4 } & No comment Total & 9 & 12.9 \\
\hline & $\mathbf{7 0}$ & $\mathbf{1 0 0 . 0}$ \\
\hline
\end{tabular}




\begin{tabular}{|l|l|c|c|}
\hline Type of $\begin{array}{l}\text { Tulnerability } \\
\text { Experienced by Students }\end{array}$ & Loss of concentration & 15 & 21.4 \\
\cline { 2 - 5 } & Bad academic results & 9 & 12.9 \\
\hline \multicolumn{2}{|r|}{ Total } & $\mathbf{7 0}$ & $\mathbf{1 0 0 . 0}$ \\
\hline $\begin{array}{l}\text { Contemplation to commit any } \\
\text { destructive activity (Suicide attempt) }\end{array}$ & Yes & 2 & 2.9 \\
\cline { 2 - 5 } & No & 68 & 97.1 \\
\hline \multicolumn{2}{|r|}{ Total } & $\mathbf{7 0}$ & $\mathbf{1 0 0 . 0}$ \\
\hline
\end{tabular}

According to Table 5 in this study the consequences are classified into helplessness and insecurities, mental suspension, family isolation, anxiety and aggression and fear of further victimization. Here, 38.6 percent respondent has experienced helplessness and insecurities and 30.0 percent respondent experienced anxiety and aggression because of such victimization. So, it can be said that Facebook victimization creates a feeling of insecurity to the victim. Table 5 also represents the vulnerability experienced by the student.Total 24 respondents said that they have experienced academic vulnerability among them 21.4 percent said they lost their concentration and 12.9 percent said they have experienced bad academic result. Besides, Table 5 also focuses that 2.9 percent respondent thought to be destructive to her or thought to commit suicide. So, it can be said that apart from the other consequences, Facebook victimization could sometimes instigate a female to commit suicide.

\section{Preventive Measures Taken to Reduce Victimization}

Table 6: Preventive Measures Taken to Reduce Victimization

\begin{tabular}{|c|c|c|c|}
\hline \multirow{4}{*}{$\begin{array}{l}\text { Privacy Options on } \\
\text { Facebook }\end{array}$} & $\begin{array}{c}\text { Preventive Measures Taken } \\
\text { to Reduce Victimization }\end{array}$ & Number & Percent (\%) \\
\hline & Know and use them & 48 & 68.6 \\
\hline & Know but don't use & 6 & 8.6 \\
\hline & Don't know & 16 & 22.9 \\
\hline \multicolumn{2}{|r|}{ Total } & 70 & 100.0 \\
\hline \multirow{5}{*}{$\begin{array}{l}\text { Reasons behind Non- } \\
\text { complaint } \\
\text { To Police/ Law } \\
\text { enforcement officials }\end{array}$} & Fear of harassment & 5 & 7.1 \\
\hline & Fear of humiliation & 4 & 5.7 \\
\hline & It causes a little suffering & 19 & 27.1 \\
\hline & $\begin{array}{l}\text { Tried to solve problem } \\
\text { via outsourcing }\end{array}$ & 18 & 25.7 \\
\hline & Don't know about reporting & 24 & 34.3 \\
\hline \multirow{2}{*}{\multicolumn{2}{|c|}{ Familiarity with ICT Act, }} & 70 & 100.0 \\
\hline & & 15 & 21.4 \\
\hline $\begin{array}{l}\text { Familiarity with ICT Act, } \\
2006\end{array}$ & No & 55 & 78.6 \\
\hline \multicolumn{2}{|r|}{ Total } & 70 & 100.0 \\
\hline
\end{tabular}

In this study, Table 6 focuses on the current situation of the privacy policies of respondent's Facebook account. It shows that 68.6 percent respondent know and use the privacy policies on Facebook. From this study, although they are using privacy policies they are not safe in Facebook at all. Table 6 also represents reason behind not reporting the crime to police. Study shows that 34.3 percent respondent don't even know about reporting and 25.7 percent trying to solve problem through outsourcing capacity. So, the attitude towards reporting should enhance to avoid further victimization. Besides, Table 6 also shows that 78.6 percent victims don't have any idea about ICT act 2006.It can be said that the victims don't even know that the crime committed against them is punishable.

\section{Relationship between Age of Respondent and Crime Victimization}


In this study, Table 7 identifies the relationship between the age of the respondents and the crime she had subjected in Facebook. Here, the age groups of respondent are classified in different age group. On the other hand, crime had subjected by the respondents in social networking sites are defined in hacking and account takeover cyber bullying, cyber stalking, sexting, cloning, defamation and scams. From the following table, maximum 42.9 percent female respondents are being victimized by hacking whose are belongs to the age of 18 to 20 whereas 14.3 percent female students victimized by hacking and account takeover in 21 to 23 years age group .In 21 to 23 years age group female students (42.9 percent) are victimized by sexting and 28.6 percent are being victimized by cloning. The maximum respondents (66.7 percent) who are humiliated belong to the age group of 24 to 26. So, Facebook crime has gone beyond hacking and 15 to 20 years age group are in the most vulnerable position.

Table 7: Relationship between Crime and Age of the Respondent (Cross-Tabulation)

\begin{tabular}{|c|c|c|c|c|c|c|c|c|}
\hline \multirow{4}{*}{$\begin{array}{l}\begin{array}{c}\text { Age in } \\
\text { category }\end{array} \\
15-17\end{array}$} & \multicolumn{7}{|c|}{ Nature of Crime } & \multirow{3}{*}{$\begin{array}{c}\text { Total } \\
32 \\
\end{array}$} \\
\hline & \multicolumn{2}{|c|}{$\begin{array}{c}\text { Hacking } \\
\text { and account } \\
\text { takeover }\end{array}$} & \multirow{2}{*}{$\begin{array}{c}\begin{array}{c}\text { Cyber } \\
\text { bullying }\end{array} \\
\text { \& stalking } \\
7\end{array}$} & \multirow{2}{*}{$\begin{array}{c}\text { Sexting } \\
0\end{array}$} & \multirow{2}{*}{$\begin{array}{c}\text { Cloning } \\
9\end{array}$} & \multirow{2}{*}{$\begin{array}{c}\text { Defamation } \\
6\end{array}$} & \multirow{2}{*}{$\begin{array}{c}\text { Scams } \\
2 \\
\end{array}$} & \\
\hline & Number & 8 & & & & & & \\
\hline & Percent & $25.0 \%$ & $21.9 \%$ & $0.0 \%$ & $28.1 \%$ & $18.8 \%$ & $6.2 \%$ & $100.0 \%$ \\
\hline \multirow{2}{*}{$18-20$} & Number & 12 & 0 & 8 & 6 & 2 & 0 & 28 \\
\hline & Percent & $42.9 \%$ & $0.0 \%$ & $28.6 \%$ & $21.4 \%$ & $7.1 \%$ & $0.0 \%$ & $100.0 \%$ \\
\hline \multirow{2}{*}{$21-23$} & Number & 1 & 0 & 3 & 2 & 1 & 0 & 7 \\
\hline & Percent & $14.3 \%$ & $0.0 \%$ & $42.9 \%$ & $28.6 \%$ & $14.3 \%$ & $0.0 \%$ & $100.0 \%$ \\
\hline \multirow{2}{*}{$24-26$} & Number & 1 & 0 & 0 & 0 & 2 & 0 & 3 \\
\hline & Percent & $33.3 \%$ & $0.0 \%$ & $0.0 \%$ & $0.0 \%$ & $66.7 \%$ & $0.0 \%$ & $100.0 \%$ \\
\hline \multirow{2}{*}{ Total } & Number & 22 & 7 & 11 & 17 & 11 & 2 & 70 \\
\hline & Percent & $31.4 \%$ & $10.0 \%$ & $15.7 \%$ & $24.3 \%$ & $15.7 \%$ & $2.9 \%$ & $100.0 \%$ \\
\hline
\end{tabular}

\section{Relationship between Spending Hours on Facebook and Crime Victimization}

Table 8: Relationship between Spending Hours on Facebook and Crime Victimization (Cross-Tabulation)

\begin{tabular}{|c|c|c|c|c|c|c|c|c|c|c|}
\hline \multirow[t]{2}{*}{ Crimes } & \multicolumn{9}{|c|}{ Hours Spend on Facebook (Weekly) } & \multirow[t]{2}{*}{ Total } \\
\hline & 1 & 7 & 14 & 21 & 28 & 35 & 42 & 70 & & \\
\hline \multirow[t]{2}{*}{ Hacking } & $\mathrm{N}$ & 0 & 5 & 1 & 2 & 5 & 0 & 0 & 9 & 22 \\
\hline & $\%$ & $0.0 \%$ & $29.4 \%$ & $14.3 \%$ & $66.7 \%$ & $45.5 \%$ & $0.0 \%$ & $0.0 \%$ & $40.9 \%$ & $31.4 \%$ \\
\hline \multirow{2}{*}{$\begin{array}{l}\text { Cyber } \\
\text { bullying \& } \\
\text { stalking }\end{array}$} & $\mathrm{N}$ & 0 & 1 & 4 & 0 & 1 & 0 & 0 & 1 & 7 \\
\hline & $\%$ & $0.0 \%$ & $5.9 \%$ & $57.1 \%$ & $0.0 \%$ & $9.1 \%$ & $0.0 \%$ & $0.0 \%$ & $4.5 \%$ & $10.0 \%$ \\
\hline \multirow[t]{2}{*}{ Sexting } & $\mathrm{N}$ & 1 & 4 & 1 & 0 & 0 & 1 & 0 & 4 & 11 \\
\hline & $\%$ & $100.0 \%$ & $23.5 \%$ & $14.3 \%$ & $0.0 \%$ & $0.0 \%$ & $20.0 \%$ & $0.0 \%$ & $18.2 \%$ & $15.7 \%$ \\
\hline \multirow[t]{2}{*}{ Cloning } & $\mathrm{N}$ & 0 & 3 & 1 & 1 & 2 & 3 & 2 & 5 & 17 \\
\hline & $\%$ & $0.0 \%$ & $17.6 \%$ & $14.3 \%$ & $33.3 \%$ & $18.2 \%$ & $60.0 \%$ & $50.0 \%$ & $22.7 \%$ & $24.3 \%$ \\
\hline \multirow[t]{2}{*}{ Defamation } & $\mathrm{N}$ & 0 & 4 & 0 & 0 & 3 & 1 & 2 & 1 & 11 \\
\hline & $\%$ & $0.0 \%$ & $23.5 \%$ & $0.0 \%$ & $0.0 \%$ & $27.3 \%$ & $20.0 \%$ & $50.0 \%$ & $4.5 \%$ & $15.7 \%$ \\
\hline \multirow[t]{2}{*}{ Scams } & $\mathrm{N}$ & 0 & 0 & 0 & 0 & 0 & 0 & 0 & 2 & 2 \\
\hline & $\%$ & $0.0 \%$ & $0.0 \%$ & $0.0 \%$ & $0.0 \%$ & $0.0 \%$ & $0.0 \%$ & $0.0 \%$ & $9.1 \%$ & $2.9 \%$ \\
\hline \multirow{2}{*}{\multicolumn{2}{|c|}{ Total }} & 1 & 17 & 7 & 3 & 11 & 5 & 4 & 22 & 70 \\
\hline & & $100.0 \%$ & $100.0 \%$ & $100.0 \%$ & $100.0 \%$ & $100.0 \%$ & $100.0 \%$ & $100.0 \%$ & $100.0 \%$ & $100.0 \%$ \\
\hline
\end{tabular}


In this study, Table 8 shows the relationship between hours spent by the user in Facebook and the risk of crime victimization. It interprets that 66.7 percent victims of hacking spent 21 hours weekly on Facebook and most of the victim (57.1 percent) of bullying use Facebook for 14 hours weekly. This study also shows that 60.6 and 50.0 percent of cloning victim are using Facebook for either 35 or 42 hours. Besides, those who are using Facebook for only one hour are not safe at all and being subjected to sexting. Again those who are daily spending in an average 10 hours on Facebook is mostly ( 40.9 percent) become the victim of hacking and cloning (22.7 percent).

\section{Relationship between Time of Facebook Usage and Nature of Crime}

Table 9: Relationship between Time of Facebook Usage and Crime (Cross-Tabulation)

\begin{tabular}{|c|c|c|c|c|}
\hline \multicolumn{2}{|c|}{ Time of Facebook Usage } & Hacking & Others & Total \\
\hline \multirow[t]{2}{*}{ Daytime } & Number & 7 & 11 & 18 \\
\hline & Percent & $31.8 \%$ & $22.9 \%$ & $25.7 \%$ \\
\hline \multirow[t]{2}{*}{ Night } & Number & 8 & 27 & 35 \\
\hline & Percent & $36.4 \%$ & $56.2 \%$ & $50.0 \%$ \\
\hline \multirow[t]{2}{*}{ Constantly } & Number & 7 & 10 & 17 \\
\hline & Percent & $31.8 \%$ & $20.8 \%$ & 24.3 \\
\hline \multirow[t]{2}{*}{ Total } & Number & 22 & 48 & 70 \\
\hline & Percent & $100.0 \%$ & $100.0 \%$ & $100.0 \%$ \\
\hline
\end{tabular}

According to Table 8, this study shows the relationship between the time of Facebook usage and the types of crime they are subjected to. This study shows that half of the victim (50 percent) use Facebook at night. It also figured out that most of the hacking victim (36.4 percent) and other crime victim 56.2 percent are those who are using Facebook at night. Apparently it can be said that those who are using Facebook at night are more prone to be victim than those who used it at daytime.

\section{Relationship between Age and Type of Vulnerability Experienced by Student}

Table 10: Relationship between age and type of vulnerability experienced by students (Cross-Tabulation)

\begin{tabular}{|l|l|c|c|c|}
\hline \multirow{2}{*}{$\begin{array}{l}\text { Age of the } \\
\text { respondent }\end{array}$} & \multicolumn{2}{|c|}{ Academic vulnerability Experienced by Students } & \multirow{2}{*}{ Total } \\
\cline { 2 - 5 } & & Loss of concentration & Bad academic results & \\
\hline \multirow{2}{*}{$15-17$} & Number & 4 & 6 & 10 \\
\cline { 2 - 5 } & Percent & $40.0 \%$ & $60.0 \%$ & $100.0 \%$ \\
\hline \multirow{2}{*}{$\mathbf{1 8 - 2 0}$} & Number & 7 & 1 & 8 \\
\cline { 2 - 5 } & Percent & $87.5 \%$ & $12.5 \%$ & $100.0 \%$ \\
\hline \multirow{2}{*}{$21-23$} & Number & 3 & $25.0 \%$ & $100.0 \%$ \\
\cline { 2 - 5 } & Percent & $75.0 \%$ & 1 & 2 \\
\hline \multirow{2}{*}{ Total } & Number & 1 & $50.0 \%$ & $100.0 \%$ \\
\cline { 2 - 5 } & Percent & $50.0 \%$ & 9 & 24 \\
\cline { 2 - 5 } & Number & 15 & $37.5 \%$ & $100.0 \%$ \\
\hline
\end{tabular}

In this study, Table 10 represents the relationship between age of the respondent and vulnerability they had experienced. In sum 62.5 percent respondent lost their concentration and 37.5 percent had experienced bad academic results. Most of the victim (87.5 percent) who lost their concentration belongs to the age group of 18 to 20 years and 
60 percent victim who belongs to the age of 15 to 17 years has experienced bad academic results. It also figured out that 75 percent respondent of 21 to 23 years age lost their concentration in response to their victimization. So, when the question arises about academic performance 15 to 20 years aged female users in of Facebook are more vulnerable to Facebook victimization than the rest age group.

\section{TESTS OF HYPOTHESIS}

\section{Hypothesis Test 1}

Null Hypothesis: Crime victimization in Facebook doesn't depend on the types of friend someone have in Facebook.

Alternative Hypothesis: Crime victimization in Facebook depends on the types of friend someone have in Facebook.

According to Hypothesis test table 4.7.1, Pearson Chi-Square value is 6.701Degrees of freedom is 2 and $\mathrm{p}$ value is $0.035(\mathrm{p}<0.05)$.But, in 2 degrees of freedom the table value $=$ 5.991. As, calculated value $>$ table value; the null hypothesis is rejected and alternative hypothesis is accepted. It can be said that these two variables are not independent rather dependent. That means there is a statistically significant relationship between the types of friends on Facebook and the nature of crime that the victims are subjected to.

Hypothesis Test Table 1: Chi-Square Test

\begin{tabular}{|l|c|c|c|c|}
\hline & Value & $\mathrm{df}$ & Significance level & Table Value \\
\hline Pearson Chi-Square & 6.701 & 2 & .035 & 5.991 \\
\hline
\end{tabular}

\section{Hypothesis Test 2}

Null Hypothesis: There is no relationship between the nature of crime and which of the daytime someone is using Facebook.

Alternative Hypothesis: Crime victimization in Facebook depends on the time of Facebook usage.

According to Hypothesis test table 4.7.2, Pearson Chi-Square value is 14.284, degrees of freedom is 10 and $p$ value is 0.160 ( $p>0$.05). That's why there is no statistically significant relationship between these two variables and the null hypothesis is accepted. So, there is no statistically significant relationship between which of the day time someone is using Facebook with crime. So, victimization in Facebook never depends on which of the daytime someone is using Facebook.

Hypothesis Test Table 2: Chi-Square Test

\begin{tabular}{|c|c|c|c|}
\hline & Value & $\mathrm{df}$ & Significance level \\
\hline Pearson Chi Square & 14.284 & 10 & .160 \\
\hline
\end{tabular}

\section{CONCLUSION}

Over the last several years, teenage and adult have benefited from the advancement of computer and technology. By using quantitative techniques this study tried to find the intersection between Facebook usage and crime. Study shows that the gratifications of using Facebook by the teenagers and young adults tend to outweigh the perceived threats. This study also demonstrates that a 15 to 17 years aged female are victimized more than 
others and as the age increased the rate of victimization decreased. Victims those are tried to be destructive were the victim of defamation and was victimized by their known one. A common strategy to avoid victimization in Facebook may be non-disclosure of private information and photograph on Facebook, but this is a very weak mechanism to eliminate Facebook related victimization. Most users do not seem to know that these crimes are punishable. Eventually, a permanent long term solution is needed to reduce Facebook victimization of female.

\section{REFERENCES}

Dinerman, B. (2011).Social networking and security risks. Retrieved at 11 December 2016 from http:/ / www.gfi.com.

Halder, D., \& Jaishankar, K. (2013). Use and Misuse of Internet by Semi-Urban and Rural Youth in India: A Baseline Survey Report. Tirunelveli, India: Centre for Cyber Victim Counselling

Jeet, S. (2012).Cybercrimes against women in India: Information Technology Act, 2000. Elixir International Journal.

Livingstone, S. (2008). Internet Literacy: Young People's negotiation of new Online Opportunities in Digital Youth. Innovation and the Unexpected, 4, ed. T. McPherson, The MIT Press, Cambridge, MA, 101-122.

Lovejoy, J.P. (2009). Facebook and Online Privacy: Attitudes, Behaviors, and Unintended Consequences. Journal of Computer Mediated Communication. Retrieved at March 82017 from doi:10.1111/j.1083-6101.2009.01494.x

Maruf, A.M, Islam, M.R \& Ahmed, B. (2010). Emerging Cyber Threats in Bangladesh: In Quest of Effective Legal Remedies. The Northern University Journal of Law, 1.

Ngo, F.T \&Paternoster, R. (2011). Cybercrime Victimization: An examination of Individual and Situational level factors. International Journal of Cyber Criminology.

Notar, C.E, Padgett. S \& Roden. J. (2013), Cyber Bullying: A review of Literature. Universal Journal of Educational Research, Retrieved at June 62017 from 10.13189/ujer.2013.010101

Perry, J. (2012). Digital Stalking: A guide to technology risks for victims. Network for Surviving Stalking and Women's Aid Federation of England.

Soron T. R \& Chowdhury, C. A. (2016). Facebook, Violence and Safety of Children in Bangladesh. Journal of Psychiatry, Vol 19, Retrieved at 2 April 2017 from 368, doi:10.4172/2378-5756.1000368.

The Daily Bangladesh Somoy. (2016). Vulgarity in Facebook Live is Increasing Facebook Harassment Retrieved at 16 April 2017.

United Nations Broadband Commission for Digital Development (2010).Cyber Violence against Women and Girls. Retrieved at 16 April 2017 from www.broadbandcommisssion.org 
Publish Online and Print Version Both

Online ISSN: 2312-2021

Google Scholar: https://goo.gl/eozEWi 